\title{
Indigenous knowledge, world view and institution for sustainable community at Mappi regency of West Papua
}

\author{
Taslim Dawan $^{1, *}$, Sjafril Darana $^{1}$, M Ade M Kramadibrata $^{1}$ \\ ${ }^{1}$ Indonesian Resource Center for Indigenous Knowledge, University of Padjadjaran, Bandung, Indonesia \\ *Corresponding author
}

\section{ABSTRACT}

Efforts to preserve the culture and the environment in indigenous communities followed the increase in the standard of living of course requires a relatively long time. The value of each ethnic cultural roots, however very worth keeping, at stake, given than there actually human beings need to realize that each of his creations have the same rights and obligations. One of them raised pattern of life in the region of Mappi, Papua. The existence of protection forests now only $30 \%$. The concept of participatory and biodiversity protection spatialised significant value yet. Weak participatory concept can hinder development, especially customary community has long occupied. Legal protection for the people is necessary, with regard to start pouring newcomers. Land use to meet the needs of daily life as the alternative areas have not been met. Fish catches, fishing locations governed by custom maintained, especially after the discovery of contamination of nonlocal seashell fish that is able to eliminate local germplasm. The use of firearms illegal hunting should be set based on strict rules. Gaps health status of indigenous peoples of the immigrants is felt. Facts discovered during this needs to be addressed through the "Poverty Reduction Approaches and Model" both in terms of the "Integrated Finance and non-finance service for sustainable poverty reduction". Solution approach can be applied to the system dynamics method that aims to link the problems of the factors noted above can be solved simultaneously and comprehensively by involving various aspects related disciplines.

Keywords: Indigenous knowledge, world view and institution, sustainable, Mappi West Papua

\section{INTRODUCTION}

Papua is the largest island with have ethnic culture diversity, and most of the environment has not been widely explored as well, like in other developed provinces in Indonesia. However, unlike the case for one of the districts in the south, namely Mappi. Reality is quite a lot of newcomers to contest, and factual they even become permanent residents. Broadly speaking, could be understood, considering that the region is rich in natural resources, such as aloes, amber, crocodile leather, rattan, fish and shrimp as well as wood. Even though population is dwindling due to declining forest land, birds of paradise, cassowary, including kangaroos, while orchid has not been utilized, including cultivated.

The livelihoods of indigenous people, generally as gatherers and fishermen fish in the river. The indigenous people in meeting the demands of everyday life generally look for sago for staple food, hunting wild animals such as wild boar, cassowary birds, kangaroos and so forth. If after a food source depleted, they move elsewhere in order to obtain other purposes to obtain the purposes until a certain time. Protected areas, including protected forests and cultivated areas and limited production forests, forest production can be converted, residential, estates, farms, swamps, savannahs, and open land.

Protected areas Mappi region is divided into two (2) sections, namely forest based land use and function of forest areas and forests are divided into a variety of primary, secondary, mangrove and marsh. Almost all districts (15 districts) has a swamp. Based on the functions of forests are protected forests and concentrated in estuaries Digoel, foot KOK, estuary times Yuliana. Production forests are divided into permanent production forest, limited production forest and convertible production forest are in the whole district.

The total population of 85129 inhabitants in 2011, with an area of $28518 \mathrm{~km}$, with a sharing type, which means that men and women 44261 and 40868 inhabitants. The existence of the largest population located in the district 
of Obaa which is used as a regional center of government, in general, partially of the population embraced Christianity Catholic and Protestant, and in districts Mappi there are four (4) tribes big that Yachai, Auyu, Wiyachar, and Tamario, plus the other tribes, namely Kima-Ghima, Uyagan, Mustard, and Bisman mostly as a gatherer societies.

Their rapidly developing educational facilities in the district are 7 units kindergarten, 84 units Elementary School, 59 units of private Primary Schools, 8 Junior High School and Private 4, and 5 or Vocational High School. In the health facilities and infrastructure in 2011 there are 1 hospital and 11 health centers.

\section{METHOD}

Mappi-West Papua is a region on the scope of the environmental assessment indigenous existence or existential of indigenous people through institutional thinking to a sustainable society based with the descriptive method approach. No other, is expected to be found a pattern of appropriate policies in order to improve their standard of living in the midst of globalization, without leaving the noble cultural values that have a good asset for the nation, the state building, and even the world at once.

\section{RESULTS}

\section{Geography and Regional Administration}

Geographically, Mappi located between $06^{\circ} 28^{\prime}-56^{\circ} 4^{\prime}$ East Longitude and $5^{\circ}-9^{\circ}$ South Latitude with an area of $28518 \mathrm{~km}^{2}$ and has a height $0-100 \mathrm{~m}$ above sea level, meaning in hot regions.

\section{Figure 1. Mappi-Regency of West Papua Map}

The physical condition including disaster-prone areas comes from 15 District, there are 10, that is NambiomanBapai; Edera; Obaa; Haju; Assue; Citak Mitak; Kaibar;Passue; Minyamur; and Venaha.

The protective region is divided into two parts, namely forest based land use and function of forest area, and then divided into categories of primary, secondary, mangroves and swamps of 2,680,462.87 ha. Keep in mind the reality of forest in Mappi now $\pm 30 \%$.

In addition the relevant district has 14 rivers, namely Digoel; Edera; Maapi; He; obaa; Bapai; Widelman; Dear am; Yuliana; Assue; Freskap; Purmi; Surung; and Sawa, with a long stretch between 95-180 km;20-900m wide; and a depth of 4-28 m.

Consisting of clean water in four rivers: Tompura $(0.72$ $\left.\mathrm{m}^{3} / \mathrm{sec}\right)$; Inarape $\left(0.14 \mathrm{~m}^{3} / \mathrm{sec}\right)$; Dakenem $\left(0.09 \mathrm{~m}^{3} /\right.$ $\mathrm{sec})$; and Kaltimoghon (0.03 $\left.\mathrm{m}^{3} / \mathrm{sec}\right)$. The population of the male population 44261 inhabitants and 40868 inhabitants (2011) with constellations gender $=1.08$.

\section{Social and Culture}

Some areas locations are found locations that are considered sacred, and one District Edera in Gimika Village there is Busun archaeological site and sacred Yuduba for local people interst. The traditional house in Venaha District and other districts should not be changed and fixed function must be preserved. The lives of indigenous people, most still depend on nature, including wild boar hunting, cassowary, paradise, kangaroo, and non-original deer.

The pattern of nomadic genuine people, mostly are still in progress and highly dependent on food supplies. Upon return to the native village they keep doing as gatherers and fishermen fish in the rivers as well as smaller coastal fishing in the sea. Indeed, the existence of agricultural land in their native village is considerable potential, but considering natural resources they are still low. The ability to run in agricultural land is very less. As a result, abandoned agricultural land, since not worked intensively.

\section{Education}

Mappi have 7 kindergarten with 36 teachers and 416 pupils (2011). Elementary School 84,288 teachers with 1,121 students. Private Elementary Schools 59,252 teachers and 8,408 students. Private school signifies a favorite, given that his education mostly come from migrant communities. There are 8114 Junior High School, with 114 teachers, and 2,302 students. While, there are 8 Junior High School with 114 teachers, and 981students. Five High Schools with 106 teachers and 1.587 students are also by large come from newcomers' people.

The condition associated with a population of 85129 people, in 15 Districts of Mappi Rigency spread relatively far away from the center of government in Obaa District. It is a health problem where still far from the meeting demands. It is seemingly still finding people who are disabled as many as 413 people (2011) in spite of already relatively far less than in 2010 as many as 807 people. 
HIV / AIDS is also found as many as 11 people aged 2029 years (2011), with as many as 14740 people of childbearing age in the Obaa District. Family Planning active participants who had injections of 3,578 people and 1,161 people pills.

Cases of diseases in district Mappi (2011) are: Diarrhea; Malaria; Intestinal Infections; Mushrooms Dermatoses; Worms; The Infected Skin; Dental Caries, and Malaria Tersiana. These factors provide a general overview, that environmental factors determine the level of health.

The above can be explained via the magnitude of the poverty line and the number of poor people, known in 2008 amounted to $36.23 \%$; in 2009 amounted to $34.94 \%$; and 2010 was $33.12 \%$. The reality of an opinion, that the rate of decline poverty levels in the Mappi district is very small. Indicating a pattern of life and community life requires a new policy in dealing with patterns of poverty.

\section{Economy}

The economy of agrarian is still patterned in Mappi Regency, as well as the characteristics of most of regencies or city in Papua Provinces.

Table 1. The role of each business field from Regional Gross Domestic Product (GDP) (2007-2011) (\%)

Clearly there seems to be three big things that play a role in Mappi namely: 1. Agriculture; 2. services; and 3. building gives a general picture, that agricultural issues should be a major concern in the follow services, even the buildings began to appear prominent. Indicates can be anticipated, why Mappi forest to day still 30 percent.

\section{DISCUSSION}

Mappi-West Papua has the potential of natural resources, whether it be the primary and secondary forest, mangroves and swamps should be exploitation with attention to sustainable systems. The existence of strategic geography is in tropical areas make the district concerned has summer and rainy climate, so popular with immigrants and are set to be local residents.

The existence of indigenous Papua in Mappi generally as gatherers and fishermen fish in the river should be developed, although most of the rivers have been known Gastor kind of stranger predator fish called tilapia, is malignant and make the fish germplasm wane, even feared extinct.

Lifestyle of the people migrating or nomadic cause some problems, such as children's education is dependent and neglected, followed by the stability of food availability is difficult to determine, as well as the more worrying regarding the soundness of them hard to detect. In addition, firstly the native village is potential, but because of given the human resources is low so resulting in disrepair, not explored intensively.

The impact of lifestyle system, lack of education, followed by health reduced level support involving them in the lowest poverty line.

Mappi Regency economic relies heavily on three major business field, namely agriculture $23.61 \%$; services 26.60\%; and the largest building $36.45 \%$ (2011) provides an overview, that is no doubt why the existence of forests still $30 \%$. Indicating that it's a lot of primary and secondary forest, the trees going into building materials.

\section{CONCLUDING REMARK}

West Papua Mappi-very feasible to be developed in the form of structural and infrastructural development. Nevertheless, the existence of indigenous lifestyle is necessary to find an approach that is considered to be effective and efficient in an effort empowerment, namely with dynamic system model, because all of institution were involved. Involvement of all aspects of good policy from upstream to downstream, expected problems could be solved simultaneously.

Assets original culture of indigenous Papua, especially those in Mappi Regency not be lost simply due to the advent of the era of globalization. Then this means the world community are also encouraged to participate will pay attention to the customs preservation of the Papua indigenous people.

\section{ACKNOWLEDGEMENT}

- $\quad$ Our team would like thank to the infinite forwarded of Business Economics Faculty Head Economics in given attention opportunity to the articles research.

- No forget, the same phrase to the Rector of the Padjadjaran University which was willing to give a chance anyway. 
- Government Mappi Regency of West Papua who had been working together very well in the framework of cooperation in the field of Environmental Assessment strategy (2011-2031).

\section{REFERENCE}

Regional Development Planning Board (Bappeda) Mappi. 2011. Spatial Plan (RTRW) Year 2011-2031.

Regional Development Planning Board (Bappeda) Mappi. 2013. List of village and village in Mappi.

The Central Statistics Agency (BPS) Mappi. Mappi in Figures 2012.

The Central Statistics Agency (BPS) Mappi. Gross Regional Domestic Product Mappi 2011, BPS Mappi

Center for Watershed Management (BP DAS) Memberamo (document)

Public Works Department Mappi (Report).

Department of Transportation Mappi (Report).

Papua Provincial Transport Department. Transport the level of 2012. The provinces of Papua.

Directorate of Environmental Geology, Ministry of Energy and Mineral Resources of the Republic of Indonesia (document).

Directorate of Water Resources, Ministry of Public Works (document).

Institutions Research and Industrial Affiliation Institute of Technology Bandung (LAPI-ITB) and the Regional Development Planning Board (Bappeda) Mappi. 2011. Final Report Survey Potential Areas Mappi Papua Province.

Research Institute Unhas with Planning Agency of Regional Development (BP3D) Mappi. 2008.

Tourism Development Master Plan (RIPP) Mappi Papua Province.

\section{LPKL Binalab Bandung 2011 (Analysis)}

Murdjiono and Indri Quraini. 2008. Destruction of Life Indigenous Auyu: Investment Impact Oil Above Auyu
Tribe Indigenous Land in the Territory Getentiri Digoel.Foker LSM Papua.

Alma mater Merauke Foundation and the United Nations Development Programme (UNDP). 2005.

Final Report: Study of Existence and capacity of CSO / $\mathrm{CBO}$ and the Sustainable Livelihoods Communities in the 4 districts in Southern Papua region. March. Merauke.

Kartikasari, Sri Nurani, Andrew J. Marshall, Bruce M. Beehler (Ed.). 2012. Ecology of Papua. Jakarta: Indonesia Obro Foundation and Conservation International.

Provincial Government Department of Culture. 2008. Map Tribe in Papua. Cooperation Papua Provincial Cultural Department, the Department of Anthropology UNCEN, Summer Institute Of Linguistics (SIL), Dewan Adat Papua (DAP) and the Central Statistics Agency (BPS).

Mappi Regional Regulation No. 7 of 2006

Mappi Regional Regulation No. 3 of 2009

Mappi Regional Regulation No. 11 of 2011

Regulation of the Minister of Environment of the Republic of Indonesia Number 9 Year 2011

Law No. 26 of 2002

Law No. 26 of 2007

Law No. 32 of 2009

WWF Indonesia. 2010. Report of Identification Fields, Reconciliation and Workshops: Participatory Mapping Important Sites of Indigenous Peoples in Mappi.

WWF Indonesia. 2010. Report on the Identification and Assessment of High Conservation Values at Asmat and Mappi.

radiosuaradogiyaifm.blogspot.com (accessed on 8 November 2013)

Anonymous, 2013. https://www.google.co.id/ url? $\mathrm{Sa}=\mathrm{t}$ $\& \mathrm{rct}=\mathrm{j} \& \mathrm{q}=\& \mathrm{ESRC}=\mathrm{s} \&$ source $=$ web $\& \mathrm{~cd}=5 \&$ $\mathrm{cad}=\mathrm{fw} \& \mathrm{ved}=0 \mathrm{CEAQFjAE} \& \operatorname{url}=\mathrm{http} \% 3 \mathrm{~A} \%$ 
2F\% 2Fpotensidaerah.ugm.ac. id\% 2Fdata\% 2F431_PERIKANAN.doc \& eiXYV8Uo3EDce5rgfLIID4Dg \& usg = AFQjCNGnVIOfq2XxqV3E6v2Kj-eMRLcJ6w \& BVM $=$ bv.56146854, d.bmk (accessed on 8 November 2013)

www.bappeda-mappi.com (accessed on 8 November www.bapesdalh.papua.go.id (accessed on 8 November 2013)

www.sigpertambanganpapua.com (accessed on 8 November 2013)

Figure 1. Mappi-Regency of West Papua Map

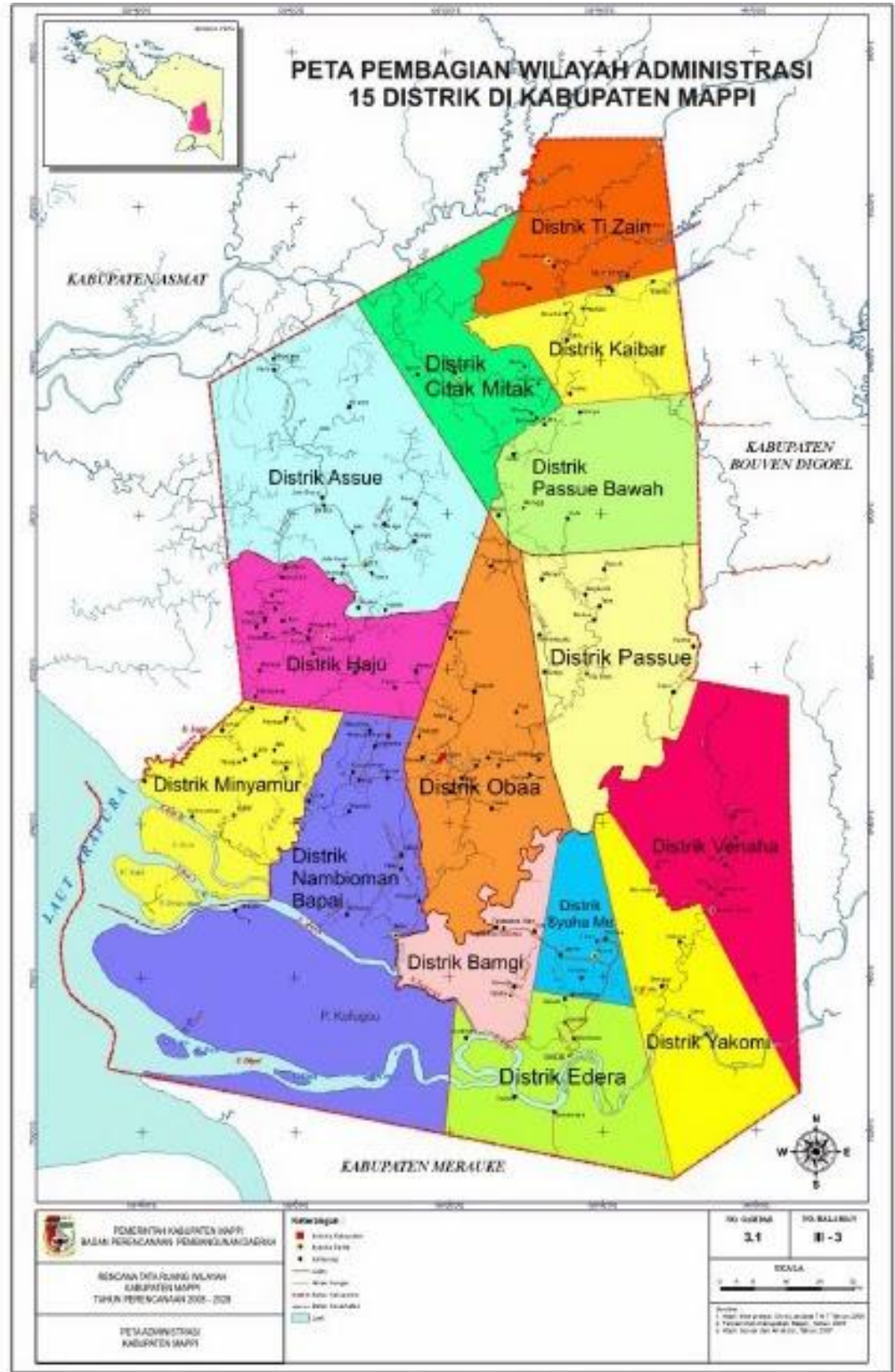


Table 1. The role of each business field from Regional Gross Domestic Product (GDP) (2007-2011) (\%)

\begin{tabular}{|c|c|c|c|c|c|c|}
\hline No. & Business field & 2007 & 2008 & 2009 & 2010 & 2011 \\
\hline 1 & Agriculture & 31.08 & 26.40 & 23.88 & 23.75 & 23.61 \\
\hline & Mining & & & & & \\
\hline 2 & excavation & 0.47 & 0.45 & 0.44 & 0.43 & 0.44 \\
\hline 3 & Processing industry & 0.43 & 0.38 & 0.34 & 0.33 & 0.31 \\
\hline & Electricity and & & & & & \\
\hline 4 & Water & 0.00 & 0.00 & 0.00 & 0.00 & 0.00 \\
\hline 5 & Building & 26.48 & 29.72 & 34.79 & 35.17 & 36.45 \\
\hline & Trade Hotel and & & & & & \\
\hline 6 & Restaurant & 7.25 & 7.15 & 7,27 & 7.30 & 7.95 \\
\hline 7 & $\begin{array}{l}\text { Transport and } \\
\text { Communications }\end{array}$ & 4.24 & 9.03 & 3.95 & 3.93 & 3.94 \\
\hline & $\begin{array}{l}\text { Finance, Real Estate, } \\
\text { and Business }\end{array}$ & & & & & \\
\hline 8 & Services & 1.36 & 1.40 & 1.22 & 1.28 & 1.12 \\
\hline 9 & Services & 28.67 & 34.47 & 28.11 & 27.81 & 26.20 \\
\hline
\end{tabular}

Source: Gross Domestic Product 2011, BPS, Mappi Regency West Papua 